\title{
The Mediating Effect of Innovation on Entrepreneurial Competencies and Business Success in Malaysian SMEs
}

\author{
Azmi Umar ${ }^{1}$, Che Mohd Zulkifli Che Omar ${ }^{2}$, Mohd Sahandri Gani Hamzah ${ }^{3}$, Azizah Hashim ${ }^{1}$ \\ ${ }^{1}$ Faculty of Management \& Economics, Sultan Idris Education University (UPSI), Malaysia \\ ${ }^{2}$ Associate Professor, Faculty of Management \& Economics, Sultan Idris Education University (UPSI), Malaysia \\ ${ }^{3}$ Professor, Chancellor Office of Academic \& International, Sultan Idris Education University (UPSI), Malaysia \\ Correspondence: Azmi Umar, Faculty of Management \& Economics, Sultan Idris Education University (UPSI) \\ 35900 Tanjung Malim, Perak, Malaysia.
}

Received: June 19, 2018

doi:10.5539/ibr.v11n8p142

\author{
Accepted: July 13, 2018 \\ Online Published: July 25, 2018 \\ URL: https://doi.org/10.5539/ibr.v11n8p142
}

\begin{abstract}
The purpose of this paper is to explore the extent of entrepreneurial competencies and innovation on business success in SMEs in Malaysia. Specifically, this study tested the mediating role of product innovation and process innovation between the relationship of entrepreneurial competencies and business success. The statical sample population of this research includes 407 owner and manager involved in SMEs, both manufacturing and services $\&$ other sectors. For data collection, a standard questionnaire using seven-point Likert scale and 72 items was used to evaluate 12 entrepreneurial competencies (strategic competency, commitment competency, conceptual competency, opportunity competency, organising and leading competency, relationship competency, learning competency, personal competency, technical competency, familism competency, ethical competency \& social responsibility competency), seven items for innovation (product \& process innovation) and, ten items for business success (financial \& non-financial). Four hypotheses were developed in this study. The SPSS version 21.0 and Structural equation model (SEM)-AMOS version 21.0 techniques were used. The findings indicate that there is a positive and significant relationship between the entrepreneurial competencies and innovation on business success in SMEs. Moreover, there is a positive and significant relationship between all dimension of competencies and business success. The product innovation and process innovation served as partial mediator between entrepreneurial competencies and business success. Limitations and implications for future studies are discussed.
\end{abstract}

Keywords: entrepreneurial competencies, innovation, business success, SMEs, Malaysia

\section{Introduction}

In developing country like Malaysia, SMEs are seen as a mechanism to improve the distribution of income, to stimulate economic growth, and to reshape an economic structure which has been highly depending on the activities of large firms (Mohsin, Halim, Ahmad, \& Farhana, 2017; Murjan, 2012). This is seconded by Prime Minister of Malaysia claimed that SMEs are the backbone of Malaysian economy (SME Annual Report, 2017). Approximately $99.3 \%$ of business established in Malaysia are SMEs (Ndubisi \& Salleh, 2006). However, they contributed only $31 \%$ to Malaysia's Gross Domestic Product (GDP), which is relatively small compared to other countries (Nambiar, 2009).

The contribution of SMEs to GDP's Malaysia has shown an increased trend each year from $33.0 \%$ in the year 2012 to $36.6 \%$ in the year 2016 (SME Annual Report, 2017). In others ASEAN country, the contribution of SMEs towards GDP is more significant compared to Malaysia. SMEs in Indonesia contributed 59\% (Asian Development Bank, 2017) and in Singapore, 99\% of their business established are SMEs with total number 180,000 enterprises which contributed $49 \%$ to GDP and employed $70 \%$ of Singapore's workforce (Ministry Trade \& Industry of Singapore, 2012). Given that increasing the chances of success among SMEs would huge implications for the growth and socio-economic wellbeing of a country (Asia-Pacific Economic Cooperation [APEC], 2004), understanding predictors of success in SMEs is critical.

Lopa and Bose (2014), suggested that in the long run, entrepreneurs should focus on entrepreneurial competencies for business survival and better future business success. This is consistent with a study done by 
Central Bank of Malaysia (2003) urged that entrepreneurial spirit possessed by entrepreneurs and good programme for human resource development give an impact to SMEs business success (Central Bank of Malaysia, 2003; SME Corp Survey, 2010). Sánchez (2012) suggested that entrepreneurial competencies have an impact on business success. Entrepreneurial competencies are a significant contributor to a firm's success. In Malaysia perspective, Ahmad, Ramayah, Wilson, \& Kummerow (2010) suggested that entrepreneurial competencies were strong predictors of business success and it was found that the association between entrepreneurial competencies and business success was more strongly evident in hostile and dynamic environments than in more benign and stable environments, however more studies should be conducted. Thus, this paper attempts to investigate the relationship of the entrepreneurial competencies on business success with the inclusion of innovation as mediating effect. As SMEs, the innovation is highly recommended and it is thefore interesting to explore how entrepreneurial competencies and innovation enhance firm's success.

\section{Literature Review and Conceptual Framework}

Alvarez and Busenitz (2001), claimed that Resource Based Theory (RBT) and entrepreneurship involve the founders/owners unique awareness of opportunities, the ability to acquire the resource needed to exploit the opportunity, and the organisational ability to recombine homogeneous inputs into heterogeneous outputs. Barney (1991) urged that the entrepreneurial competencies are the key sources belong to entrepreneurs (people), and people are human capital that categorised as an intangible asset of firms that enable them to be more successful. Entrepreneurial competencies referred as the underlying characteristics such as traits, self-image, specific knowledge, motives, social roles and skills that lead to venture, survival its growth (Bird, 1995). Ahmad et al. (2010) suggested that entrepreneurial competencies such as the behaviour, skill, knowledge and attitude possesed by entrepreneurs themself were the factors that determine the success of the business. Whereas Sa'ari, Adenan, Hashim, and Jamaludin (2013) defined them as a cluster of the set of related knowledge, attitudes, and skills of entrepreneurs to produce performance and maximise profit.

Many positive relationships between entrepreneurial competencies and performance have been noted by a number of researchers (Al-Damen \& Ali, 2015; Xiaogang \& Xinchun, 2005; Tanoira \& Valencia, 2014). Entrepreneurial competencies are also connected directly to better export performance (Ibeh, 2003), and success in terms of firm size and economic growth (Tang, Wang, \& Zhang, 2007). Studies have also found a positive effect of entrepreneurial competencies on the growth of small firm (Gurbuz \& Aykol, 2009) and profitability of non-state firms in China (Xiaogang \& Xinchun, 2005). Some scholars suggested that entrepreneurial competencies are needed to start a business (Tatar, 2013), while managerial skills much needed during growing stage. A study was done by Man (2001) identified eight domains of entrepreneurial competencies namely; strategic, commitment, conceptual, opportunity, organising \& leading, relationship, learning and personal. Another scholar, Chandler \& Jansen (1992) urged technical competency as one of the entrepreneurial competencies. This domain was extended by Ahmad (2007) urged that ethical, social responsibility and familism as part of entrepreneurial competencies.

A recent study by Kazemi, Rasekh, and Navid (2016) in Iran revealed that there is a positive and significant relationship between the variables of competencies (strategic, relationship, conceptual, personal, opportunity, learning, ethical, and familism) and innovation. Results in that study also claimed that $77 \%$ innovative change as fostered by entrepreneurial competencies indicative of a strong impact of the entrepreneurial competencies on innovation and performance of enterprises. Strategic competency was the major influenced among the all entrepreneurial competencies towards innovation. Another study done in West Midlands, U.K based on 245 manufacturers in SMEs revealed that technical competency, strategic competency and, organising and leading competency was percieved as most important factors to improve innovation in the firms (Freel, 1999).

Given the circumstances today, innovation is accepted as a necessity and is a vital resource for a firm's sustainability and growth (SME Master Plan 2012-2020; Varis \& Littunen, 2010). Innovation is useful as its benefits exceed the cost of the resources to implement it (Niera, Lindman, \& Fernandez, 2009). A recent study was done by Ilker and Birdogan (2011), product innovation and process innovation have a strong and positive relationship in determining the business success in SMEs. In manufacturing sector in Malaysia show that innovation has a positive relationship with business success and the entrepreneurs were suggested to focus more on innovation to enhance the customer's satisfaction (Mohsin, et al., 2017).

Previous researchers found that the SMEs are often more innovative than large firms (Afuah, 2003). SMEs tend to respond efficiently to customer needs than larger organisations (Berthon, Ewing, \& Napoli, 2008), as they are more flexible (Acs \& Audretsch, 1988). SMEs' innovative capabilities contribute to valuable economic and social contributions. In Malaysia, innovation is increasingly important and focus as one of the key areas under 
Malaysia SME Master Plan 2012 - 2020 (SME Master Plan 2012-2020). Based on The Global Innovation Index 2015 issued by World Intellectual Property Organisation (WIPO, 2015), Malaysia was ranked number 32 in innovation performance compared to 141 countries. There are four domains of innovation in SMEs; product innovation, process innovation, organisation innovation, and market innovation (Varis \& Littunen, 2010). However, product and process innovation were the most frequently employed domains in innovation study in SMEs (Tang, 2006; Wang \& Ahmed, 2004). According to Ilker and Birdogan (2011), product innovation and process innovation have a strong and positive relationship in determining the business success in SMEs. Figure 1 displayed the conceptual framework for this study.

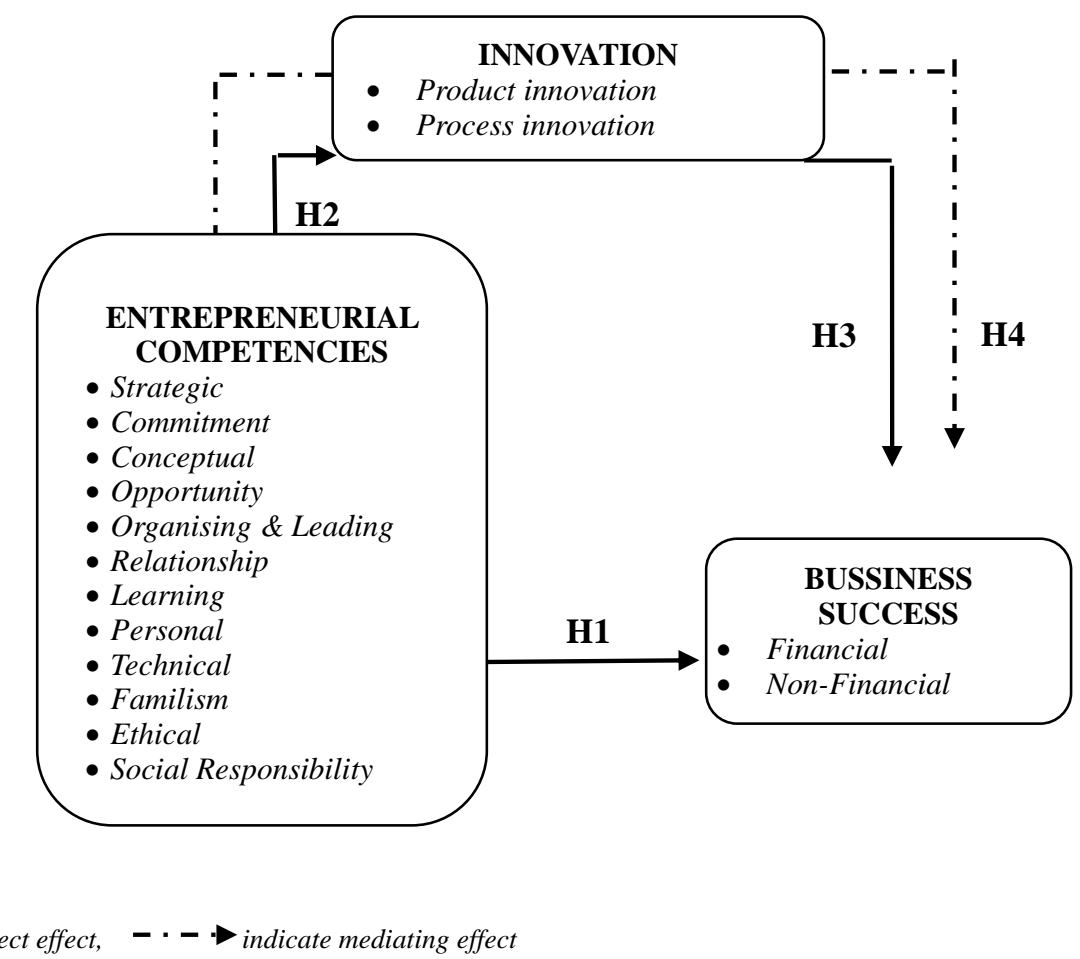

Figure 1. The Conceptual Framework of Study

\section{Hypotheses Developed}

\section{Entrepreneurial Competencies and Business Success}

An entrepreneurial competencies responds to Ahmad et al. (2010), Vijaya et al. (2015), Umeze and Ohen (2015), and, Castellanos, Merino, and Zambrano (2011) suggested that there is a significant impact of entrepreneurial competencies and business success. Strong entrepreneurial competencies shown by entrepreneurs will lead to better business success in terms of business growth, sales performance, revenue, market share, return on investment, quality of products and self-satisfaction.

Hypothesis 1. Entrepreneurial competencies have a significant impact on business success.

\section{Entrepreneurial Competencies and Innovation}

Bougrain and Haudeville (2002) found that in the previous century, $60 \%$ of the innovations were in the SME sector, but many of them were not successful due to lack of professionalism and inability to collaborate with other enterprises. Kazemi et al., (2016) found a significant positive impact of entrepreneurial competencies on innovation.

Hypothesis 2. Entrepreneurial competencies have a significant impact on innovation.

\section{Innovation and Business Success}

The organisation's ability to innovate and provide a solution to satisfy customer needs could improve its performance (Weerawardena, 2003). Innovation is accepted as a necessity, and it is a vital resource for firms' sustainability and growth, and to ensure SMEs' success in long-term (Murjan, 2012; Rosenburch et al., 2011).

Hypothesis 3. Innovation has a significant impact on business success. 


\section{Innovation as a Mediator}

Nasuredin, Halipah, and Shamsudin (2016) that entrepreneurial competencies affected the business success in SMEs. Rosenbusch et al. (2011) urged that innovation has a positive effect on SME performance and business success. Innovation is useful as its benefits exceed the cost of the resources to implement it (Niera et al., 2009), and Kazemi et al. (2016) found a significant positive impact between innovation and entrepreneurial competencies.

Hypothesis 4. Innovation mediates the relationship between entrepreneurial competencies and business success.

\section{Research Methodology}

The present descriptive study is correlation types an utilizes a regression analysis (SEM) and falls into the category of empirical research. As the study variables need to be evaluated and their impact is measured for each outcome, and as the outcome are to be applicable for a large group of observations, the quantitative approach is adopted for this study. Moreover, as the data were collected at one specific point of time, it is considered a cross-sectional study. The number of subjects in the population that meets the definitions in Malaysian SMEs consists of 47,698 in manufacturing sectors and, 859,367 in services and other sectors (Economic Census, 2016). However this study was conducted in Klang Valley and Selangor because of its energetic and dynamic economic activities that give benefits to the growth of SMEs in the region consists of Kuala Lumpur and its suburbs, and adjoining cities and town in the state of Selangor (Suhaimi et al., 2015).

As a questionnaire was used as a data collection instruments. In order to evaluate entrepreneurial competencies, innovation and business success, we used the questionnaires of entrepreneurial competencies developed by Man (2001) 52 items, Ahmad (2007) 16 items and, Chandler \& Jansen (1992) 4 items; innovation by Szymanski and Henard (2000) 4 items and, Murjan (2012) 3 items; business success by Chandler \& Hanks (1993) 5 items and, Hoque (2004) 5 items. Items statements in the variables sections are measured as subjective estimates using a seven-point Likert scale (with $1=$ strongly unimportant to $7=$ strongly important for entrepreneurial competencies, and $1=$ strongly disagree to $7=$ strongly agree for inovation and business success).

The Composite Reliability (CR), and Average Variance Extracted (AVE) were used to measure reliability and validity. Table 1 presents the composite reliability and validity for each construct of the entrepreneurial competencies, innovation, and business success. According to Awang et al. (2015) and Hair, Babin, and Krey (2017), the acceptable value for CR and AVE is 0.70 and 0.50 respectively. The higher value of CR and AVE, the more reliable and valid of the construct to be tested. In this study, all constructs are satisfied since the value for $\mathrm{CR}$ and AVE are greater than the recommended value. Specifically, the range value for CR is between 0.846 and 0.920 , and value for AVE for each construct was fall between 0.568 and 0.715 .

Table 1. Composite realibility

\begin{tabular}{lcc}
\hline Construct & CR & AVE \\
\hline Business Success & 0.933 & 0.874 \\
Financial & 0.881 & 0.596 \\
Non-Financial & 0.881 & 0.598 \\
Entrepreneurial competencies & 0.940 & 0.883 \\
Familism & 0.879 & 0.593 \\
Technical & 0.856 & 0.597 \\
Opportunity & 0.846 & 0.579 \\
Relationship & 0.871 & 0.575 \\
Ethical & 0.888 & 0.570 \\
Conceptual & 0.887 & 0.568 \\
Learning & 0.875 & 0.583 \\
Personal & 0.910 & 0.590 \\
Social Responsibility & 0.848 & 0.582 \\
\hline Organising \& Learning & 0.920 & 0.589 \\
Strategic & 0.908 & 0.585 \\
Innovation & 0.938 & 0.884 \\
Process & 0.829 & 0.619 \\
Product & 0.909 & 0.715 \\
\hline
\end{tabular}

Table 2 showed the value of construct correlations and Square Root Average Variance Extracted (SQAVE). The discriminant validity is considered satisfied when the value of SQAVE (bold value) is greater than the value of construct correlation as recommended by Hair et al., (2017) and, Fornell and Larcker (1981). Apart from that, the value of construct correlations must be below than 0.85 . Therefore, this discriminant validity was satisfied and can proceed to test the hypotheses between constructs involved in the current study. 
Table 2. Discriminant Validity

\begin{tabular}{lccc}
\hline Construct & $\begin{array}{c}\text { Entrepreneurial } \\
\text { Competencies }\end{array}$ & Innovation & $\begin{array}{c}\text { Business } \\
\text { Success }\end{array}$ \\
\hline Entrepreneurial Competencies & $\mathbf{0 . 9 3 9}$ & $\mathbf{0 . 9 4 0}$ & \\
Innovation & 0.56 & 0.54 & $\mathbf{0 . 9 3 8}$ \\
Business Success & 0.53 & \\
\hline
\end{tabular}

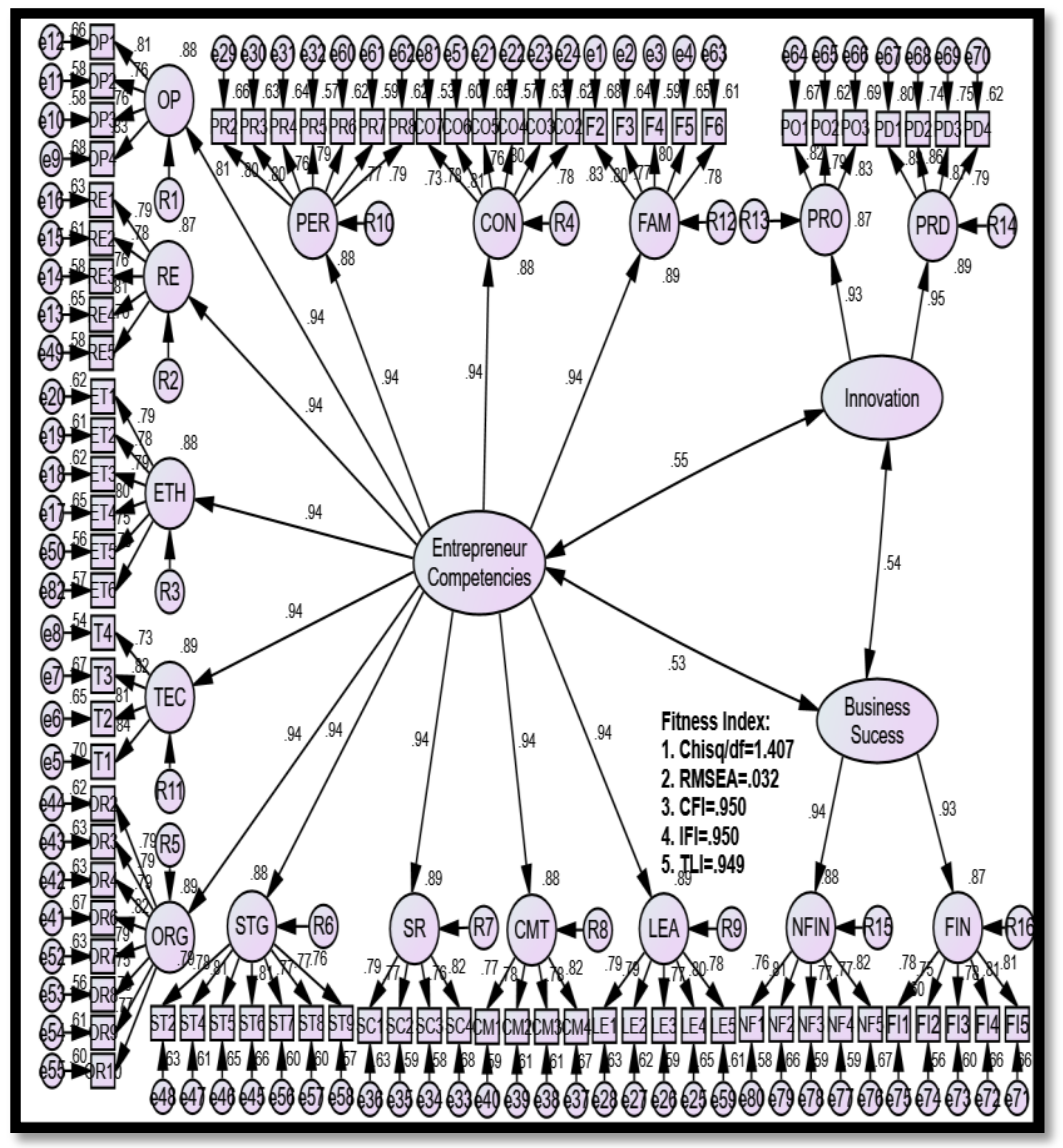

Note. FIN = Financial, $N$-FIN = Non Financial, FAM = Familism, TEC $=$ Technical, $O P=$ Opportunity, $R E=$ Relationship, ETH $=$ Ethical, $C O N=$ Conceptual,$L E A=$ Learning,$P E R=$ Personal,$S R=$ Social Responsibility, $O R G=$ Organising \& Learning,$S T G=$ Strategic , $P R O=$ Process Innovation, $P R D=$ Product Innovation

Figure 2. Pool CFA

In addition, all the fitness index for pooled CFA were achieved as suggested by Hair et al. (2017) as displayed in Figure 2. Specifically, the absolute fit represented by RMSEA $=0.032<0.08$; incremental fit represented by CFI $=0.950, \mathrm{TLI}=0.949$, and IFI $=0.950$; and parsimonious fit represented by Chisq $/ \mathrm{df}=1.4047<3.0$.

The normality assessment can be identified by skewness analysis which is all items must fall between -1.5 to 1.5 (Awang, 2015) and the kurtosis acceptable value for kurtosis is in the range between -3.0 to 3.0 (Lowry \& Gaskin, 2014). In this study, the skewness is between -1.5 to .28 and kurtosis between -.44 to .39 . Moreover, multivariate of kurtosis identified 1.835 which is lower than 50.0 as recommended value by Awang (2015).

\section{Research Findings}

In this study majority of the respondents $(89.7 \%)$ were males, while the rest $(10.3 \%)$ were females. With respect of races, majority of the respondents were Malay (54.3\%), Chinese (40.3\%), Indian (4.4\%) and other races (1\%). As regards age, that the majority of the respondents (45.2\%) fall within the range 41-50 years and followed by 51-60 years (40.3\%). Moreover, $45.2 \%$ of the owner/managers went into business venturing in the age of 41-50 years. With respect to education level, $43 \%$ of the owners/managers of SMEs were degree holders, 39\% diploma holders, 9\% certificate holders, 5\% high school, $4 \%$ master holders, and 1\% had a Ph.D./Doctoral qualification. 
With respect to working experience prior running the business, almost all respondents (92.9\%) had working experience prior running the business and $7.1 \%$ respondents only had no previous working experience. It is reported that majority of the respondents have start-up experience (57.7\%) and $42.3 \%$ of the entrepreneurs have no prior business start-up experience. With respects to firm type, $11.3 \%$ of the respondents reported that their business is operating in manufacturing, $86.0 \%$ in the services and $2.7 \%$ in other sector.

Hypothesis 1. Entrepreneurial competencies have a significant impact on business success.

From Table 3, the regression weight estimate of 0.190 has a standard error of 0.051 . The critical ratio is shown as 3.742 standard errors above zero. The probability of getting a critical ratio of $3.742 \mathrm{in}$ an absolute value is 0.001 . Therefore, the hypothesis that entrepreneurial competencies have a positive and significant effect on business success is highly supported.

\section{Hypothesis 2. Entrepreneurial competencies have a significant impact on innovation.}

From Table 3, the regression weight estimate of 0.198 has a standard error of 0.013 . The critical ratio is shown as 15.650 standard errors above zero. The probability of getting a critical ratio of 15.650 in an absolute value is 0.001 . Therefore, the hypothesis that entrepreneurial competencies have a positive and significant effect on innovation is highly supported.

\section{Hypothesis 3. Innovation has a significant impact on business success.}

From Table 3, the regression weight estimate of 1.035 has a standard error of 0.226 . The critical ratio is shown as 4.576 standard errors above zero. The probability of getting a critical ratio of $4.576 \mathrm{in}$ an absolute value is 0.001 . Therefore, the hypothesis that innovation has a positive and significant effect on business success is highly supported.

Table 3. Regression Weight

\begin{tabular}{|c|c|c|c|c|c|c|c|}
\hline & & & Estimate & S.E. & C.R. & $\mathbf{P}$ & Result \\
\hline $\begin{array}{l}\text { Business } \\
\text { Success }\end{array}$ & $<--$ & $\begin{array}{l}\text { Entrepreneurial } \\
\text { Competencies }\end{array}$ & .190 & .051 & 3.742 & $* * *$ & Significant \\
\hline Innovation & $<---$ & $\begin{array}{l}\text { Entrepreneurial } \\
\text { Competencies }\end{array}$ & .198 & .013 & 15.650 & $* * *$ & Significant \\
\hline $\begin{array}{l}\text { Business } \\
\text { Success }\end{array}$ & $<---$ & Innovation & 1.035 & .226 & 4.576 & $* * *$ & Significant \\
\hline
\end{tabular}

Hypothesis 4. Innovation mediates the relationship between entrepreneurial competencies and business success.

In this study, Baron and Kenny Approach is used to test the mediator. The indirect effect of this model taken from standardized model is $0.36(0.84 \times 0.43)$ which is the product coefficient between entrepreneurial competencies on innovation, and innovation on business success as per Figure 3. The direct effect is 0.33 that is the beta estimate from entrepreneurial competencies and business success. The mediation effect is said significant when the direct effects are significant. In this case, the mediation effect occurs in this model. In order to compute the z-test, the value of indirect effect should be significantly different from zero or must greater than the direct effect. The indirect effect for this model is 0.36 which is greater than the direct effect which 0.33 (Figure 4). According to Iacobucci, Saldanha, and Deng (2007) and, Baron and Kenny (1986), the partial mediation is said exist when the direct effect is significant. If the direct effect is reported not significant, then, full mediation occurs. In this case, direct effect was significant and therefore the type of mediation for this model is partial mediation. 


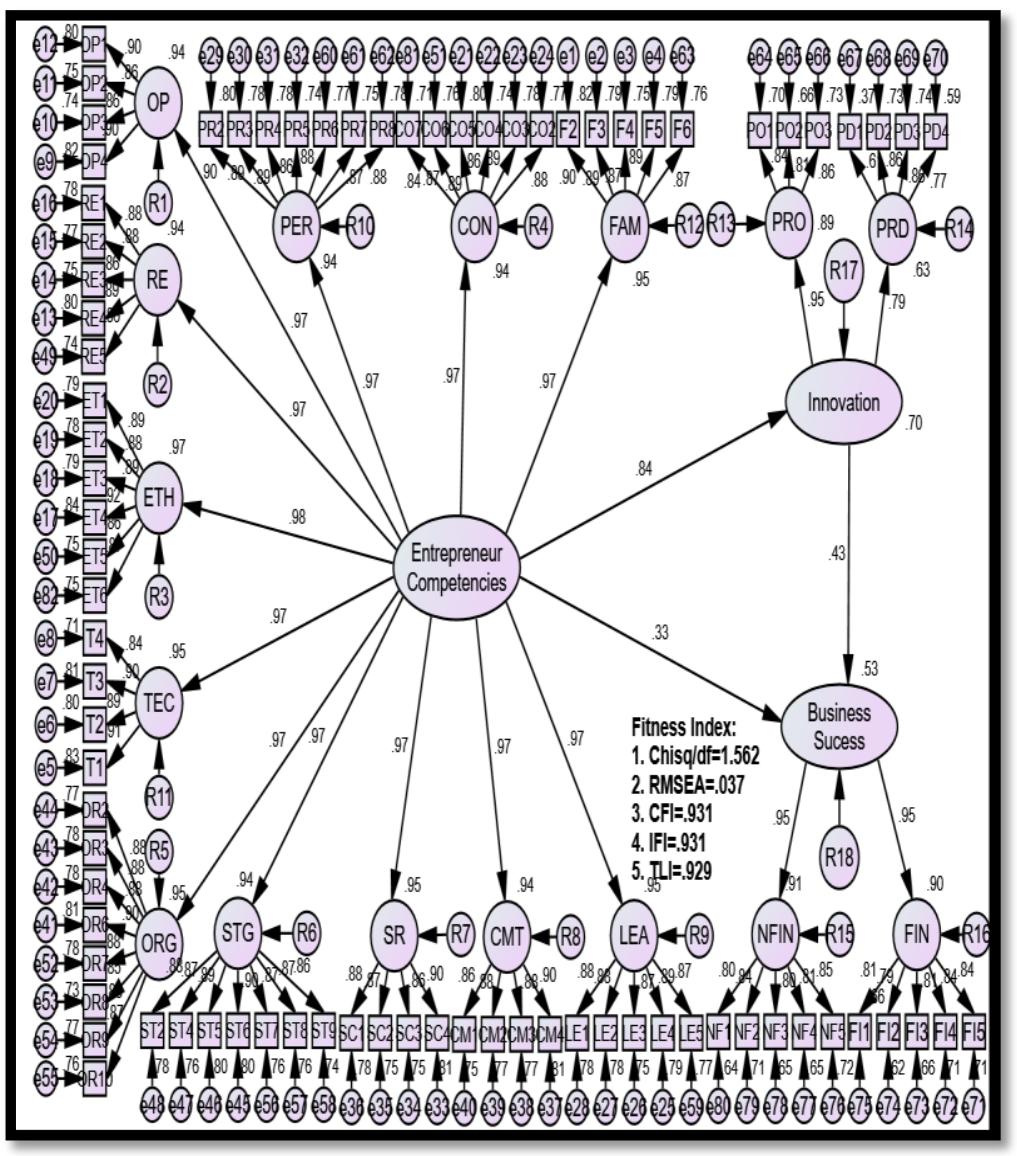

Note . FIN $=$ Financial, N-FIN $=$ Non Financial, FAM $=$ Familism, TEC $=$ Technical, OP $=$ Opportunity, RE $=$ Relationship, ETH $=$ Ethical, $\mathrm{CON}=$ Conceptual, LEA $=$ Learning, $\mathrm{PER}=$ Personal, $\mathrm{SR}=$ Social Responsibility, ORG = Organising \& Learning, $\mathrm{STG}=$ Strategic, $\mathrm{PRO}$ $=$ Process Innovation, $\mathrm{PRD}=$ Product Innovation

Figure 3. Structural Standardized Model

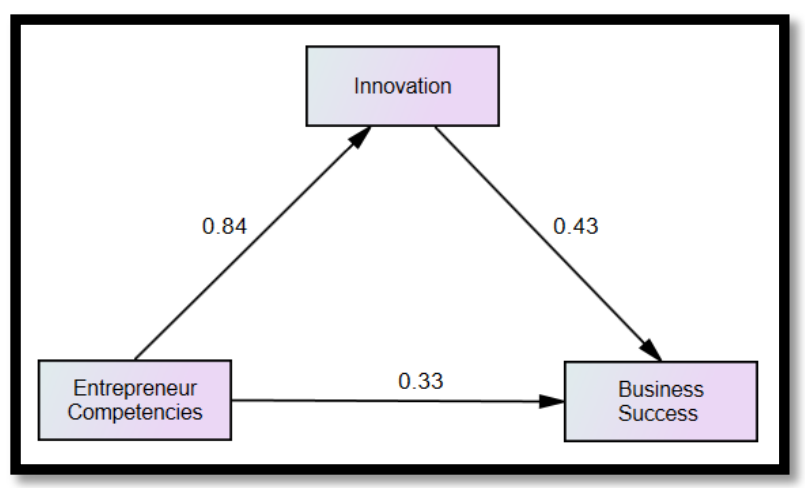

Figure 4. Testing Mediation

In order to varify the results, researchers conducted bootstrapping as per Table 4. The result for bootstrapping estimates and p-value was obtained by the application of AMOS output. The regression weight estimate for indirect effect $(\mathrm{a} \times \mathrm{b})$ is 0.359 . The probability of getting a bootstrap p-value for indirect effect is 0.002 , it means is that the regression weight for innovation as mediator construct is significant at 0.05 level, hence, the hypothesis that innovation has mediates the relationships between entrepreneurial competencies and business success is highly supported. The regression weight for direct effect is 0.332 . The probability of getting bootstrap $\mathrm{p}$-value for direct effect is 0.002 ( $\mathrm{p}$-value $<0.05)$. Therefore, it can be concluded that the type of mediation for this model is partial mediation because the significant effect existed in the direct effect. The results from bootstrapping application are consistent with Baron and Kenny approach. 
Table 4. The Result of Direct and Indirect Effect of Entrepreneurial Competencies, Innovation, and Business Success

\begin{tabular}{lcc}
\hline & Indirect Effect & Direct Effect \\
\hline Bootstrapping Estimate & 0.359 & 0.332 \\
Bootstrapping P-Value & 0.002 & 0.002 \\
Result & Significant & Significant \\
Type of Mediation & \multicolumn{2}{c}{ Partial Mediation } \\
\hline
\end{tabular}

\section{Discussion}

The aim of this paper is to evaluate the effect of entrepreneurial competencies and innovation on business success in SMEs. The results showed that there is a positive and significant relationship between entrepreneurial competencies and business success, entrepreneurial competencies and innovation and, innovation and business success. The results are consistent with studies done by Kazemi et al., (2016), Mugewa (2013), and Sa'ari et al., (2013). Moreover from this study proved that innovation acting as partial mediator between entrepreneurial competencies and business success. In light of this study, it can be concluded that entrepreneurial competencies significantly effecting the innovation particularly product and process innovation in SMEs, and finally led to business success.

From the study, its found that twelve entrepreneurial competencies; strategic competency, commitment competency, conceptual competency, opportunity competency, organising and leading competency, relationship competency, learning competency, personal competency, technical competency, familism competency, ethical competency and social responsibility competency has a positive and significant effect on business success (financial and non-financial) of SMEs in Malaysia. This means, the entrepreneurs who possess a higher level of entrepreneurial competencies generally perform better than those with lower competencies specifically in SMEs in Malaysia.

The finding from this study is consistent with the results of the study by Nasuredin et al., (2016) that entrepreneurial competencies affected the business success in Malaysian SMEs. Opportunity, organizing, and strategic competency has a significant effect towards SMEs performance will perform better or succeed in their businesses, while other competencies such as relationship competency, conceptual competency, and commitment competency were less influence towards business success (Nasuredin et al., 2016). To date, even though significant relationship were found between entrepreneurial competencies and SMEs performance, supporting the findings by Man, Lau and Snape (2008) suggested that the competence needed are different according to levels of management, sector, and organization.

It also found in this study that there is a positive and significant relationship between the conceptual competency and innovation. Based on the concept of conceptual competency, it is clear that is essential to study and survey new ideas, take risks, and understand the business concept in order to foster innovation. A recent study in sport organisations in Iran revealed that there is a positive and significant relationship between the variables of competencies (strategic, relationship, conceptual, personal, opportunity, learning, ethical, and familism) and innovation (Kazemi et al., 2016). Results in that study also claimed that $77 \%$ innovative change as fostered by entrepreneurial competencies indicative of a strong impact of the entrepreneurial competencies on innovation and performance of enterprises. Strategic competency was the major influenced among the all entrepreneurial competencies towards innovation. The positive and significant relationship between learning competency and innovation indicate that organisational learning provides a context and the requirements for the occurrence of innovation, hence improved business performance and competitive advantages (Kazemi et al., 2016).

Another study done in West Midlands, U.K based on 245 manufacturers in SMEs revealed that technical competency, strategic competency and, organising and leading competency was perceived as most important factors to improve innovation in the firms (Freel, 1999). SMEs are considered to be more innovative due to their flexibility, higher ability to adapt and improve, and they are quick movers in implementing changes. Innovation is a tool for SMEs to remain competitive and achieving higher performance (Darroch \& McNaughton, 2002). In response to changing market conditions, SMEs are able to adapt, develop new ideas, an improved existing products/services whether through major, expensive change or subtle changes as such as extensions to existing products lines (Gehlar, Regmi, Stefanou, \& Zoumas, 2009). In order to survive, SMEs must adapt to a changing industry by becoming accustomed to technological advances and create new products/services from time to time.

From this study, when product and process innovation is considered in the relationship between entrepreneurial competencies and business success, it improves the financial and non-financial success of SMEs. Innovation has yet examined as a mediator in the relationship between entrepreneurial competencies and business success (Umar \& Hashim, 2017; Umar \& Ngah, 2016), therefore no comparison is available. However, the mediating 
effect of innovation is supported by other studies in SMEs such as between market orientation and business performance (Mahmoud et al., 2016) and, entrepreneurial orientation and business performance (Keea \& Rahman, 2017).

\section{Conclusion}

This research would benefit the owner/manager of SMEs in creating an awareness of the factors that have influence on SMEs success. The entrepreneurs should be equipped with knowledge about the potential impact of their own behaviour towards the way they are operating the business. The findings of the study may give insight idea to entrepreneurs in SMEs by identifying the focus on training that might be necessary to improve the effectiveness and efficiency of business. From theoritical implication, this study highlighted the innovation served as mediator variable between entrepreneurial competencies and business success.

However, there was limitations with the design of the data collection. This study applied self - report as the source of all data. This approach, even though criticised by some, was deemed necessary because of difficulties associated with the independent assessment of each of these variables. Secondly, language choice chosen for this study posed another limitation as the survey instruments used Malay and English language. Thus, this study would have attracted more participation from Chinese entrepreneurs if the survey instruments were also available in Chinese as Malaysia is multi racial country.

For future studies the suggestion is a gender gap. It is interesting aspect of investigation would be undertaking a comparative study to ascertain whether or not there are gender differences in competency requirements. The suggestion has been made that men and women entrepreneurs manage their business somewhat differently (McGregor \& Tweed, 2001).

In conlusion, the business success in SMEs can be enhanced starting with entrepreneurial competencies, and through innovation. As the fitness index was satisfied, this research can be generalise to all SMEs regardless the status of nations.

\section{References}

Acs, Z. J., \& Audretsch, D. B. (1988). Innovation in large and small firms: an empirical analysis. The American Economic Review, 678-690.

Afuah, A. (2003). Innovation management: strategies, implementation and profits. Oxford University Press, United State of America.

Ahmad, N. (2007). A cross-cultural study of entrepreneurial competencies and entrepreneurial success in SMEs in Australia and Malaysia. Unpublished doctoral dissertation, University of Adelaide.

Ahmad, N. H, Ramayah, T., Wilson, C., \& Kummerow, L. (2010), Is entrepreneurial competency and business success relationship contingent upon business environment? International Journal of Entrepreneurial Behavior \& Research, 16(3), 182-203. https://doi.org/10.1108/13552551011042780

Al-Damen \& R. Ali (2015). The impact of entrepreneurs' characteristics on small business success at medical instruments supplies organizations in Jordan. International Journal of Business and Social Science, 6(8), 164-175.

Alvarez, S. A., \& Busenitz, L. W. (2001). The entrepreneurship of resource-based theory. Journal of Management, 27(6), 755-775. https://doi.org/10.1177/014920630102700609

Asian Development Bank. (2017). Retrieved from https://www.adb.org/data/publications

Asia-Pacific Economic Cooperation. (2004). Implementation of the SPAN. An update by Malaysia. Agenda Item No 14.

Awang, Z. (2015). SEM made simple: A gentle approach to learning Structural Equation Modeling. Kuala Lumpur.

Barney, J. (1991). Firm resources and sustained competitive advantage. Journal of Management, 17(1), 99-120. https://doi.org/10.1177/014920639101700108

Baron, R. M., \& Kenny, D. A. (1986). The moderator-mediator variable distinction in social psychological research: Conceptual, strategic, and statistical considerations. Journal of Personality and Social Psychology, 51, 1173-1182. https://doi.org/10.1037/0022-3514.51.6.1173

Berthon, P., Ewing, M. T., \& Napoli, J. (2008). Brand management in small to medium-sized enterprises. Journal of Small Business Management, 46(1), 27-45. 
https://doi.org/10.1111/j.1540-627X.2007.00229.x

Bird, B. (1995). Toward a theory of entrepreneurial competency. Advances in Entrepreneurship, Firm Emergence and Growth, 2(1), 51-72.

Bougrain, F., \& Haudeville, B. (2002). Innovation, collaboration and SMEs. Internal research capacities. Research Policy, 31(5), 735-747. https://doi.org/10.1016/S0048-7333(01)00144-5

Castellanos, A. R., Merino, J. D., \& Zambrano, L. G. (2011). Organisational knowledge, intangible resources and business performance. Journal of Knowledge Management Practice, 12(2).

Central Bank of Malaysia. (2003).

Chandler, G. N., \& Hanks, S. H. (1993). Measuring the performance of emerging businesses: A validation study. Journal of Business Venturing, 8, 391-408. https://doi.org/10.1016/0883-9026(93)90021-V

Chandler, G. N., \& Jansen, E. (1992). The founder's self-assessed competence and venture performance. Journal of Business Venturing, 7(3), 223-236. https://doi.org/10.1016/0883-9026(92)90028-P

Darroch,. J., \& McNaughton, R. (2002). Examining the link between knowledge management practices and types of innovation. Journal of Intellectual Capital, 3(3), 210-222. https://doi.org/10.1108/14691930210435570

Economic Census. (2016). Retrieved from http://www.smecorp.gov.my/images/SMEAR/latest/2/ Census\%20English_FINAL.pdf

Fornell, C., \& Larcker, D. F. (1981). Evaluating structural equation models with unobservable variables and measurement error. Journal of marketing research, 39-50. https://doi.org/10.2307/3151312

Freel, M. S. (1999). Where are the skills gaps in innovation small firms?. International Journal of Entrepreneurial Behavior \& Research, 5(3), 144-154. https://doi.org/10.1108/13552559910371095

Gehlar, M., Regmi, A., Stefanou, S. E., \& Zoumas, B. (2009). Brand leadership and product innovation as firm strategies in global food markets. Journal of Product and Brand Management, 18, 115-126. https://doi.org/10.1108/10610420910949013

Gürbüz, G., \& Aykol, S. (2009). Entrepreneurial management, entrepreneurial orientation and Turkish small firm growth. Management Research News, 32(4), 321-336. https://doi.org/10.1108/01409170910944281

Hair Jr, J. F., Babin, B. J., \& Krey, N. (2017). Covariance-Based Structural Equation Modeling in the Journal of Advertising: Review and Recommendations. Journal of Advertising, 1-15.

Hoque, Z. (2004). A contingency model of the association between strategy, environmental uncertainty and performance measurement: impact on organisational performance. International Business Review, 13(4), 485-502. https://doi.org/10.1016/j.ibusrev.2004.04.003

Iacobucci, D., Saldanha, N., \& Deng, X. (2007). A meditation on mediation: Evidence that structural equations models perform better than regressions. Journal of Consumer Psychology, 17(2), 139-153. https://doi.org/10.1016/S1057-7408(07)70020-7

Ibeh, K. I. (2003). Toward a contingency framework of export entrepreneurship: conceptualisations and empirical evidence. Small Business Economics, 20(1), 49-68. https://doi.org/10.1023/A:1020244404241

Ilker, M. A., \& Birdogan B., (2011). Antecedents and performance impacts of product versus process innovation: Empirical evidence from SMEs located in Turkish science and technology parks. European Journal of Innovation Management, 14(2), 172-206. https://doi.org/10.1108/14601061111124885

Kazemi, R., Rasekh, M., \& Navid, M. (2016). The effect of entrepreneurial competencies on innovation: A case study of professional sport clubs. International Business Research, 9(11), 57-65. https://doi.org/10.5539/ibr.v9n11p57

Keea, D. M. H., \& Rahman, N. A. (2017). Entrepreneurial orientation, innovation and smes performance: A study of SMEs in Malaysia using PLS-SEM. Paper presented at 3rd International Conference on Advanced Research in Business and Social Sciences, 129-135, Langkawi.

Lopa, N. Z., \& Bose, T. K. (2014). Relationship between entrepreneurial competencies of SME owners/managers and firm performance: A study on manufacturing SMEs in Khulna City. Journal of Entrepreneurship and Management, 3(3).

Lowry, P. B., \& Gaskin, J. (2014). Partial least squares (PLS) structural equation modelling (SEM) for building 
and testing behavioural causal theory: When to choose it and how to use it. IEEE Transactions on Professional Communication, 57(2), 123-146. https://doi.org/10.1109/TPC.2014.2312452

Mahmoud, M. A., Blankson, C., Frimpong, N. C., Nwankwo, S., \& Trang, T. P. (2016). Market orientation, learning orientation and business performance: The mediating role of innovation. International Journal of Bank Marketing, 34(5), 623-648. https://doi.org/10.1108/IJBM-04-2015-0057

Man, T. W., Lau, T., \& Snape, E. (2008). Entrepreneurial competencies and the performance of small and medium enterprises: an investigation through a framework of competitiveness. Journal of Small Business \& Entrepreneurship, 21(3), 257-276. https://doi.org/10.1080/08276331.2008.10593424

Man, W. Y. T. (2001). Entrepreneurial competencies and the performance of small and medium enterprises in the Hong Kong services sector. Unpublished doctoral thesis, The Hong Kong Polytechnic University, Hong Kong.

McGregor, J., \& Tweed, D. (2001). Gender and managerial competence: support for theories of androgyny?. Women in Management Review, 16(6), 279-287. https://doi.org/10.1108/09649420110401540

Ministry Trade and Industry of Singapore, (2012). SMEs in Singapore. Retrieved from https://www.mti.gov.sg/MTIInsights/SiteAssets/Pages/Budget2014/Growing\%20Our\%20SMEs\%20and\%2 0Micro-Enterprises\%20Booklet\%20(English).pdf

Mohsin, A., M., Halim, H. A., Ahmad, N. H., \& Farhana, N. (2017). Assessing the role of entrepreneurial competencies on innovation performance: A Partial Least Squares (PLS) Approach. Journal of Business Inquiry: Research, Education \& Application, 16(1).

Mugerwa, E. A. (2013). Entrepreneurial competencies, innovation and firm performance: a case of SMEs in Kawempe division Kampala district. Unpublished master dissertation, Makerere University, Kampala, Uganda.

Murjan, A. A. (2012). The relationship between market orientation, innovation and performance of SME sand mediating role of brand equity on SMEs Performances. Unpublished doctoral dissertation, University Utara Malaysia.

Nambiar, S. (2009). Revisiting Privatisation in Malaysia: The importance of institutional process. Asian Academic Managerial Journal, 14(2).

Nasuredin, J., Halipah, A., \& Shamsudin, A., (2016). Entrepreneurial competency and SMEs performance in Malaysia: Dynamic capabilities as mediator. International Journal of Research, 3(14), 4759-4769.

Ndubisi, N. O., \& Salleh, A. S. (2006). SMEs in Malaysia: Development Issues. NA Ndubisi and AS Salleh, Small and Medium Enterprises (SMEs): Malaysian and Global Perspectives. Selangor, Malaysia Pearson/Prentice Hall.

Neira, O. C., Tapio Lindman, M., \& Fernández, M. J. (2009). Innovation and performance in SME furniture industries: An international comparative case study. Marketing Intelligence \& Planning, 27(2), 216-232. https://doi.org/10.1108/02634500910944995

Rosenbusch, N., Brinckmann, J., \& Bausch, A. (2011). Is innovation always beneficial? A meta-analysis of the relationship between innovation and performance in SMEs. Journal of Business Venturing, 26(4), 441-457. https://doi.org/10.1016/j.jbusvent.2009.12.002

Sa'ari, H., Adenan, H., Hashim, D. A., \& Jamaludin, A. (2013). Identifying entrepreneurial competencies which lead to innovative performance in Malaysian academic libraries. Proceedings of The $4^{\text {th }}$ International Conference on Information Systems Management and Evalution, 353-360. Ho Chi Minh, Vietnam.

Sánchez, J. C. (2012). The influence of entrepreneurial competencies on small firm performance. Revista Latinoamericana de Psicología, 44(2), 165-177.

SME Annual Report 2017. Retrieved from http://www.smecorp.gov.my

SME Corp Survey, 2010. Retrieved from http://www.smecorp.gov.my

SME Master Plan 2012-2020. Retrieved from http://www.smecorp.gov.my.

Suhaimi, N. H. M., Al-Mamun, A., Zainol, N. R., Permerupan, Y., Malarvizhi, C. A., \& Nawi, N. C. (2015). Entrepreneurial competencies and performance of informal micro-enterprises in Malaysia. Mediterranean Journal of Social Sciences, 7(3), 273-281.

Szymanski, D. M., \& Henard, D. H. (2001). Customer satisfaction: A meta-analysis of the empirical 
evidence. Journal of the Academy of Marketing Science, 29(1), 16-35. https://doi.org/10.1177/0092070301291002

Tang, J. (2006). Competition and innovation behaviour. Research Policy, 35(1), 68-82. https://doi.org/10.1016/j.respol.2005.08.004

Tang, Y., Wang, P., \& Zhang, Y. (2007). Marketing and business performance of construction SMEs in China. Journal of Business \& Industrial Marketing, 22(2), 118- 125. https://doi.org/10.1108/08858620710730230

Tanoira, F. G. B., \& Valencia, R. A. S. (2014). Knowledge management, entrepreneurial competencies and organisational development in micro and small enterprises in rural regions in the state of Yucatan, Mexico. European Scientific Journal, 10(1).

Tatar, G. A. (2013). How are entrepreneurial competence and dynamic capabilities of the Norwegian IT Start-ups related to performance? University of Oslo, Norway.

Umar, A., \& Hashim, A. (2017). The mediating role of product and process innovation on the relationship between entrepreneurial competencies and business success in manufacturing companies in Malaysia. Paper presented at 4th International Conference of Rural Development and Entrepreneurship, Alor Star.

Umar, A., \& Ngah, R. (2016). The relationship of entrepreneurial competencies and business Success of Malaysian SMEs: The mediating role of innovation and brand equity. Advances in Business Research International Journal, 60-68.

Umeze, G. E., \& Ohen, S. B. (2015). Marketing mix strategies and entrepreneurial competence: Evidence from micro restaurants in Calabar Metropolis, Cross River State, Nigeria. Conference Proceedings.

Varis, M., \& Littunen, H. (2010). Types of innovation, sources of information and performance in entrepreneurial SMEs. European Journal of Innovation Management, 13(2), 128-154. https://doi.org/10.1108/14601061011040221

Vijaya, C., Das, M., \& Das, M. M. (2015). Entrepreneurship competencies and competitive advantage of Small and Medium Enterprises of Odisha - A statistical analysis. Journal Impact Factor, 6(1), 740-757.

Wang, C. L., \& Ahmed, P. K. (2004). The development and validation of the organisational innovativeness construct using confirmatory factor analysis. European Journal of Innovation Management, 7(4), 303-313. https://doi.org/10.1108/14601060410565056

Weerawardena, J. (2003). The role of marketing capability in innovation-based competitive strategy. Journal of Strategic Marketing, 11(1), 15-35. https://doi.org/10.1080/0965254032000096766

World Intellectual Property Organisation - WIPO (2015). The Global Innovation Index 2015. Retrieved from http://www.wipo.int/portal/en/index.html

Xiaogang, H., \& Xinchun, L. (2005). Entrepreneurial competence and enterprises' growth: An empirical study in China. Economic Research Journal, 10, 101-111.

\section{Copyrights}

Copyright for this article is retained by the author(s), with first publication rights granted to the journal.

This is an open-access article distributed under the terms and conditions of the Creative Commons Attribution license (http://creativecommons.org/licenses/by/4.0/). 